\title{
Introduktion
}

\section{Ulighed i sundhed}

\author{
Bagga Bjerge ${ }^{1}$ \\ Uffe Juul Jensen ${ }^{2}$ \\ Jørn Olsen ${ }^{3}$
}

${ }^{1}$ Center for Rusmiddelforskning, Aarhus Universitet

bb.crf@psy.au.dk

${ }^{2}$ Institut for Kultur og Samfund, Aarhus Universitet

${ }^{3}$ Afdeling for Klinisk Epidemiologi, Aarhus Universitet

Bjerge, Bagga; Jensen, Uffe Juul \& Olsen, Jørn. 2021. Ulighed i sundhed. Tidsskrift for Forskning i Sygdom og Samfund, nr. 35, 7-21

I det danske velfærdssamfund lovsynger vi ofte forskellighed og individualitet. Men det er ikke alle forskelle, vi værdsætter. Nogle forskelle kalder vi ulighed, og visse former for ulighed (f.eks. den stigende ulighed mellem de allerrigeste og middelklassen, og i særdeleshed de allermindst fattigste) har mødt stigende modstand over de senere år (Foreign Affairs, 2016; Piketty, 2020).

Også på sundhedsområdet er det vigtigt at beskæftige sig med grænsedragningen mellem forskelle og ulighed. Hvornår bliver en sundhedsmæssig forskel også en ulighed? Vores svar beror ikke alene på medicinske eller epidemiologiske data. Kvinder kan på vore breddegrader forvente at leve længere end mænd. Men de færreste vil hævde, at mænd derfor skal have en fortrinsstilling i vores sundhedsvæsen. Der er en forskel på kvinders og mænds forventede levealder, men normalt vil vi ikke betegne denne forskel som en ulighed. 'Ulighed' har i dag et normativt indhold: Ulighed kan man gøre noget ved, og bør man gøre noget ved.

Dette temanummer handler om ulighed i sundhed, og gennem syv meget forskellige artikler sætter nummerets forfattere fokus på, hvordan ulighed i sundhed kan opleves og forstås i dagens Danmark. Med temanummeret ønsker vi at anskueliggøre, at der er behov for at tænke og handle anderledes, hvis vi som 
sundhedssystem og samfund virkelig vil gøre noget ved udfordringer i forhold til ulighed i sundhed og ulighed i adgang hertil.

\section{Sundhedsstyrelsen og ulighed i sundhed}

Den danske sundhedsstyrelse, som har til opgave at fremme folkesundheden og skabe gode rammer for sundhedsvæsnet, opererer med følgende definition af ulighed i sundhed: "Social ulighed i sundhed er betegnelsen for det faktum, at sundhed er systematisk skævt fordelt i samfundet. Det betyder, at social position har betydning for borgernes levevilkår og sundhed, somatiske og psykiske sygdomme samt for middellevetiden" (https://www.sst.dk/da/viden/ulighed-i-sundhed 2021). Sundhedsstyrelsen slår samtidig fast, at den har til opgave at kortlægge og dokumentere, hvordan social position har betydning for sundheden, og den skal bidrage til mere lighed i sundhed gennem behandling, forebyggelse, rehabilitering og pleje, så der tages hensyn til borgernes forskellige behov.

Siden marts 2020 har Sundhedsstyrelsen brugt det meste af sine kræfter på at bekæmpe covid-19-pandemien. Men også her er målsætningen om at udforske og intervenere over for ulighed i sundhed aktuel. Det er undertiden hævdet, at pandemien rammer alle. Men nogle er mere udsatte for smitte end andre (se f.eks. Sodemann, 2020): Mennesker, der lever under dårlige boligforhold, familier hvor mange bor sammen, som har begrænsede muligheder for udendørs aktiviteter, eller mennesker der har erhverv, hvor de dagligt er i kontakt med mange mennesker (taxachauffører og buschauffører).

Sammenkædning af kortlægning, dokumentation, politik og etik viser sig når det drejer sig om intervention over for pandemien. Nedlukning af samfundet er et virksomt middel til at søge at begrænse pandemien. Men specielt i det seneste år er der stillet spørgsmål som: Hvem rammer nedlukningen? Hvilken indvirkning har det f.eks. på børn og unge, når de gennem længere tid er afskåret fra at være sammen med kammerater? Påvirker det ressourcesvage børn mest således at nedlukningen vil uddybe en allerede eksisterende ulighed? Epidemiologiske og virologiske data har bestandig holdt os informerede om pandemien aktuelle og sandsynlige opførsel, og politiske eller samfundsmæssige prioriteringer har i stigende omfang præget debatten. 


\section{Ulighed i sundhed: et historisk perspektiv}

Forskelle i sundhed har været på dagsordenen siden de gamle grækere. Platon skelner i dialogen Lovene mellem slavelæger og frie læger (2014). Slavelægerne behandler slaverne på en standardiseret måde, har ikke tid til at lytte til dem og få et indblik i deres særlige problemer. De frie læger, som behandler de frie, økonomisk uafhængige borgere, fører dialog med deres patienter og er således i stand til at give dem en individualiseret behandling. For Platon er der tale om en forskel og ikke en ulighed. Han har ingen forslag til, hvordan slaverne kunne få samme behandling som de frie borgere. Slaverne og de frie borgere er ikke lige (slaverne har en ringere stand eller status), og slaverne har derfor ikke krav på samme behandling som frie borgere.

Det er først med den franske revolution (1789-1799) og parolerne om frihed, lighed og broderskab, at ulighed i sundhed bliver et afgørende ideologisk og politisk tema i Europa. Fattigdommen hos den franske almue havde været med til at skabe grundlag for revolutionen. Revolutionens lighedsbudskab blev omsat i praksis, da man forpligtede sig på at give dem, der var ramt af fattigdom, ret til behandling ved sygdom (Rosen, 1956).

\section{Ulighed i sundhed: socialmedicinen som drivkraft}

Som nævnt er kortlægning af ulighed i sundhed i dag et vigtigt redskab for Sundhedsstyrelsen i forhold til at intervenere behandlingsmæssigt, forebyggelsesmæssigt og gennem sundhedsfremme. Men fra den græske medicin og til midten af det 18. århundrede var en sådan kortlægning (i vores betydning af det) stort set fraværende. Derfor blev samfundssyn og menneskesyn altafgørende elementer i synet på ulighed i sundhed. Først i midten af det 19. århundrede fik man redskaber i hænde til at forene dokumentation og politik omkring ulighed.

Socialmedicinens grundlægger Rudolf Virchow (1821-1902) undersøgte en tyfusepidemi, som hærgede Schlesien i 1847. Bakteriologien var i denne periode ved at finde fodfæste som en selvstændig og central, medicinsk disciplin, men Virchow argumenterede for, at tyfusepidemien ikke blot havde biologiske årsager, men også økonomiske, politiske og sociale årsager i form af 'forstyrrelser i folkemassernes liv' bl.a. økonomisk depression og arbejdsløshed (Virchow, 1849). Virchow var i stand til at gennemtænke forbindelser mellem det biologiske og sociale. Han var interdisciplinært udrustet: grundlægger af cellulærpatologien, drev medi- 
cinsk forskning i et bredt felt, havde kompetencer i statistik og antropologi. I tillæg var han politisk aktivist og medlem af Rigsdagen i Berlin. Han sammenfattede sin grundholdning i et berømt slogan: "Medicin er en samfundsvidenskab og politik er ikke andet end medicin i stor målestok" (Virchow ,1849; Ackerknecht, 1981; Jensen, 1987).

I England fik Edwin Chadwick (1800-1890) ved udformningen af sanitære reformer en rolle som Virchow havde i Tyskland. Hans 'Report on the Sanitary Conditions of the Labouring Population of Great Britain' var baseret på observationer af sammenhængen mellem forventet levealder og sociale vilkår (Chadwick, 1842).

Arven fra Virchow og Chadwich og de institutioner, de var med til at opbygge, fik en varig indflydelse på folkesundhedstænkning, praksis og politik både i og uden for Europa samt i det 20. århundrede. Frem til midten af det 20. århundrede var der opnået imponerede resultater, hvad angår forventet levealder, og dette er i vid udstrækning blevet tilskrevet ændringer i socioøkonomiske faktorer og staternes forskellige velfærdsforanstaltninger snarere end medicinsk behandling (Anand, Peter \& Sen, 2004).

Forandringerne i forventet levealder er imidlertid ikke blevet fordelt ligeligt. Der er fortsat ulighed i sundhed både inden for den enkelte nation som mellem landene. I 1980 udkom den engelske Black Report (Black, 1980), som dokumenterede omfattende ulighed i sundhed blandt socioøkonomiske grupper i England. Rapporten vakte ikke blot opmærksomhed på de britiske øer, men var en generel øjenåbner. Rapporten viste, at 30 år efter det nationale sundhedsvæsen var blevet etableret, var England præget af dyb social ulighed i relation til sundhed. Andre forskningsinitiativer var med til at sætte social ulighed i sundhed på dagsordenen. Det såkaldte Whitehall studie (ledet af Michael Marmot) omhandlede offentlig ansatte i England (Marmot, 1978). Man mente at kunne vise, at jo højere offentlig ansatte var i hierarkiet desto lavere dødelighed havde de.

Forskningsrapporterne som de nævnte stod ikke alene. Fra midt i 1970'erne og ind i 1980'erne satte internationale organisationer som WHO (World Health Organization) ulighed i sundhed højt på dagsordenen. På en konference i Alma Ata i 1978 blev der enighed om det ambitiøse program 'Sundhed for alle år 2000'; Et dokument, der forbandt videnskabelige indsigter om social ulighed i sundhed med en målrettet politik, der skulle afhjælpe problemet.

'Sundhed for alle år 2000' fik kun begrænset gennemslagskraft i praksis. I 1990'erne var det stadig den aggregerede (samlede) sundhedstilstand i befolkningerne, der var den dominerende ideologi. Men der begyndte at blæse nye vinde under betegnelsen New Public Health. I virkeligheden var det en tilbagevenden 
til den socialmedicinske arv: Optagetheden af social ulighed i sundhed, men nu med en stærkere betoning af nødvendigheden af en interdisciplinær forskning, der skulle bidrage til at belyse de mangeartede sociale processer, der har betydning for ulighed i sundhed (Anand, 2004).

\section{Velfærdsstatens sundhedsvæsen og kampen mod ulighed}

Ovenfor har vi givet et historisk rids af kampen mod social ulighed i sundhed. Gennem de seneste 70 år har denne kamp fået nye former. I de europæiske velfærdsstater håbede man, at lige og fri adgang til behandling ville være et effektivt middel i kampen for social ulighed i sundhed. I dag ved vi, at dette ikke lykkedes, men hvorfor spiller lighed i adgang til sundhed stadig en vigtig rolle i den globale diskussion og kamp om, hvorledes sundhedsvæsen bør indrettes. For at kunne besvare dette spørgsmål, er det nødvendigt at kende de politiske forskydninger og samfundsmæssige forandringer, som var med til at gøre princippet om lige adgang til hovedhjørnesten i velfærdstatens sundhedsvæsen i anden halvdel af det 20. århundrede.

Dette var først og fremmest inspireret af Englands Nationale Sundhedsvæsen (the National Health Service: NHS), der blev indviet i 1948. England havde været præget af dybe sociale forskelle; forskelle der blev uddybet under 1930'ernes økonomiske krise og forstærket under 2. verdenskrig. Engelske socialmedicinere som Cochrane havde fremhævet, hvordan den sociale ulighed betød ulighed i sundhed (bl.a. Cochrane, 1972; Jensen, 2004). Han deltog i demonstrationer i London i 1930'erne med krav om lige og fri adgang til behandling. Labour-bevægelsens krav om radikale, sociale reformer fik støtte af indflydelsesrige socialliberale forskere og professionelle.

NHS legemliggjorde ideen om den universelle velfardsstat med lige og fri adgang til behandling for alle borgere. NHS og det reformerede undervisnings- og uddannelsessystem var den praktiske og politiske realisering af en etisk-politisk ide, som rakte ud over at sikre rettigheder til de enkelte borgere. Den anerkendelse af hver enkelt, som velfærdsinstitutionerne sikrede, skulle samtidig tjene til at give de enkelte borgere en selvbevidsthed som statsborgere, som del af et nationalt fælleskab. Det skulle tjene til at svejse briterne sammen som en slags belønning for den patriotisme, de havde udvist i kampen mod det nazistiske Tyskland. 
Den lige og frie adgang til behandling i velfærdsstatens sundhedsvæsen var således ikke tænkt som et middel, som $i$ sig selv ville fremkalde lighed i sundhed på tværs af klasseskel. Det var ikke en utopi om et godt, sundt, lykkeligt og homogent samfund skabt af professionelle gennem distribution af standardiserede ydelser. Det rummede en anden utopi: Utopien om et homogent samfund, hvor deltagelse i samfundet som fællesskab i sig selv er sundhedsfremmende. Eller udtrykt i aktuelle begreber, som velfærdsstatens fædre ikke betjente sig af: At fællesskab (her i form af et nationalt fællesskab med 'social sammenhængskraft') skaber resiliens. Det vil sige modstandsdygtighed og sundhedsfremmende potentialer.

Imidlertid har lige og fri adgang til behandling og støtte ved sygdom og lidelse ikke udjævnet ulighed i sundhed. Der er givetvis mange forklaringer herpå. Men én kunne være, at den lige adgang ikke - som troet og håbet - skabte en (i sig selv sundhedsfremmende) solidaritet på tværs af sociale skel (Jensen, 1993). Under alle omstændigheder tvinger den stadigt større ulighed i sundhed også i lande, der sikrer lige adgang, os til at genoverveje ideen om betydningen af national solidaritet som middel til at fremme af sundhed og velbefindende.

\section{Medborgerskab som værn mod ulighed i sundhed}

En sådan genovervejelse fandt sted i international sundhedstænkning og planlægning allerede i 1980'erne, efterhånden som det blev klart, at efterkrigstidens og 1960'ernes velfærdsoptimisme blev gjort til skamme. Velfærdsstatens institutioner blev udfordret ikke bare af den økonomiske krise i 1970'erne og skuffende resultater af den store satsning på den universelle velfærdsstat (Cochrane, 1972). Men de neoliberale bevægelser, delvis privatisering og markedsførelse, var ikke de eneste svar på krisen. Der blev bl.a. formuleret nye svar i WHO-regi (f.eks det såkaldte Ottawa Charter), men også i en mangfoldighed af bruger- og netværksorienterede initiativer. Man tænkte nu medborgerskab anderledes end i midten af det 20. århundrede.

Den engelske sociolog T. H. Marshall har belyst de transformationer som medborgersskabsbegrebet har undergået fra de borgerlige revolutioner i Europa fra det 18. århundrede til den moderne europæiske velfærdsstat i midten og sidste del af det 20. århundrede (Marshall, 2003). I den første fase sikres de borgerlige frihedsrettigheder (bl.a. retten til at ytre sig, at forsamles). Senere kommer medborgerskab til at omfatte politiske rettigheder (bl.a. retten til at deltage i demokratiske valg). Velfærdsstaten var for Marshall kulminationen af denne udvikling af med- 
borgerbegrebet: Frihedsrettigheder og politiske rettigheder suppleres med sociale rettigheder (bl.a. retten til behandling ved sygdom, kompensation ved arbejdsløshed). For Marshall er der tale om en udviklingsproces, hvor kulminationen (sikring af sociale rettigheder) er en forudsætning for den fulde virkeliggørelse af såvel frihedsrettigheder som politiske rettigheder. Et rimeligt oplysnings- og uddannelsesniveau og sundhedstilstand er forudsætninger for at kunne nyde frihedsrettigheder og politiske rettigheder.

Medborgerskab med en række sociale rettigheder har fungeret som forudsætning for industrisamfundet, som det var indrettet i Europa i midten af det 20. århundrede. De sociale rettigheder bidrog til at integrere borgere, som på grund af sygdom eller andet ikke kunne udfylde deres normale samfundsmæssige funktion som f.eks. lønarbejder.

\section{Ulighed i sundhedsdiskurser i en dansk sammenhæng}

Også i Danmark har ulighed i sundhed i mere end 100 år været på den sundhedspolitiske dagsorden (Vallgårda, 2013; Sundhedsstyrelsen, 2020a). Allerede med sociallovene i 1890'erne begynder der at være eksplicit fokus på mindrebemidledes sundhed, f.eks. bliver der ydet statsstøtte til frivillige sygekasser for ubemidlede, således at eksempelvis landarbejdere og tyende får ekstra incitament til at indbetale midler til sikring under sygdom (Møller, 1998: 84). I 1930'ernes sociallove bliver sygekassemedlemskabet lovpligtigt for alle, således at hver samfundsborger inddrages i sundhedssystemet (Jonasen, 2004; Bjerge, 2009; Vallgårda, 2013). Adgang hertil bliver universel, og det bliver gratis, eller i det mindste næsten gratis, at modtage behandling. Endvidere kommer den første sygehuslov i 1946, der fastslår princippet om, at samfundets borgere skal have lige adgang til hospitalsvæsenet, dog primært med udgangspunkt et geografisk hensyn (Vallgårda, 2013). Der sker altså en løbende ansvarsoverførsel fra den enkelte borger til den offentlige sektor, hvor det offentlige sikkerhedsnet kommer til at spille en dominerende rolle i forhold til samfundsborgernes sundhed, og sundhedsområdet ekspanderer kraftigt. Med oliekrisen i 1973 og stigende udfordringer af autoriter, polemiseres velfærds- og sundhedspolitikken (Vallgårda, 2013; Bjerge, 2009; Jonasen, 2004), hvilket betyder nedskæringer i hospitalssystemet og mere fokus på den primære sundhedssektor og forebyggelsen. Samtidig er den frie og lige adgang til sund- 
hedssystemet stadig et vigtigt fokuspunkt. Danske socialmedicinere som f.eks. Vagn Christensen (1976) og Heinild (1968) fastholdt lighed i sundhed som mål og bekæmpelsen af ulige sociale vilkår som middel i en periode, hvor den lige adgang var kærnen i sundhedspolitikken.

Op gennem 1980'erne, 1990'erne og 2000'erne sker der imidlertid forandringer på sundhedsområdet med inspiration fra den private sektor med f.eks. fokus på udlicitering, større valgfrihed, privatisering, udgiftsstyring og konkurrence (Vallgårda, 2013; Bjerge 2009). Dog samtidig med at udgifterne til sundhedssystemet stiger med 30 \% i 2000'erne. Ulighed er fortsat et politisk fokuspunkt, og debatten tager for alvor fat i slutningen af 1990'erne, bl.a. grundet undersøgelser, der peger på, at de nordiske lande har en relativ høj grad af ulighed i sundhed sammenlignet med andre europæiske lande (Defactum, 2018). I forlængelse af denne debat og WHO's 'Commission on Social Determinants of Health' (CSDH, 2008) udarbejdes den forste nationale rapport Ulighed $i$ sundhed - årsager og indsatser i 2011 (Diderichsen et al., 2011; Sundhedsstyrelsen, 2020b), hvor sociale forhold for sundhed belyses. Op gennem 2010'erne udformes talrige rapporter og strategier, der alle har for øje at sætte fokus på ulighed i sundhed.

\section{Ulighed i sundhed i dag}

Her i begyndelsen af 2020'erne giver det derfor anledning til at gøre status over udviklingen og vilkårene for bestræbelserne med at nedbringe ulighed i sundhed. En måde at gøre det på er ved at kigge på de seneste tal fra Sundhedsstyrelsen (2020a), og tallene er mildest talt ikke opløftende: Der er ulighed i sundhed på mange områder, og uligheden er på flere parametre steget siden 1990'erne (ibid.). Selvom den generelle befolknings helbred gennemsnitligt er blevet bedre, er det ikke lykkedes at reducere den systematiske ulighed, som hersker i relation til socioøkonomiske kriterier f.eks. uddannelse, erhverv og indkomst. Forklaringerne på, hvorfor der trods talrige strategier og indsatser rettet mod ulighed i sundhed stadig findes denne skævvridning, er mange (cf. Sundhedsstyrelsen, 2020b; Vallgårda, 2019). De relaterer sig dels til den specifikke livsstil som f.eks. rygning, dels til sociale omstændigheder som f.eks. arbejdsløshed, og dels til det faktum, at alle borgergrupper reelt ikke har adgang til den samme type viden, information og hjælp, når de bliver syge, trods principper om lige adgang i sundhedssystemet.

Endvidere kan det også tilføjes, at det er en radikalt anden samfundsmæssig situation, vi lever i i dag end i midten af det 20. århundrede, hvor ulighed i sundhed 
for alvor kom på dagsordenen. Mange af de grupper, som er mest ramt af uligheden i sundhed, føler sig ekskluderet af samfundet, eller de føler, at de ikke møder forståelse for deres problemer af sundheds- og socialvæsenets professionelle. Fra de marginaliseredes position, vil Marshalls ide om et nationalt fællesskab baseret på fælles sociale rettigheder næppe have megen mening. Det drejer sig bl.a. om borgere uden tilknytning til eller med ringe tilknytning til arbejdsmarkedet og eller med helbredsproblemer f.eks. funktionelle lidelser som kronisk træthed (Jensen, 2010) eller diverse psykiatriske lidelser, hvor der ikke er nogen specifik behandling, som ville kunne afhjælpe deres problem. Uligheden rammer også borgere med anden etnisk baggrund, ældre og svækkede medborgere, som ikke har fast forankring i familie eller andre fællesskaber. Når vi vil genopfriske den videnskabelig og offentlige debat, har vi derfor behov for at tænke medborgerskab fra disse gruppers synsvinkel og under hensyntagen til de aktuelle samfundsmæssige betingelser. Eksempelvis har canadiske samfundsfilosoffer som Charles Taylor og Kymlicka (1995) analyseret de særlige udfordringer, som den multikulturelle virkelighed byder den canadiske velfærdstat, men skismaet mellem universelle rettigheder sikret af staten og gruppers forventninger og behov ud fra deres særlige vilkår og historie genfindes også i de europæiske velfærdsstater, herunder også i Danmark.

\section{Artiklernes perspektiver på ulighed i sundhed}

I det danske velfærdssystem, fastholder vi stadig nogle af de principper (f.eks. lige og fri adgang til behandling) som havde baggrund i en europæisk virkelighed efter 2. verdenskrig. Vi har brug for at gentænke medborgerskabsbegrebet og de hermed forbundne praksisser i den europæiske og globale virkelighed i dag. Det er en sådan interesse, som dette temanummer her ønsker at skabe rum for, og som artiklerne på forskellig måde søger at komme i møde. Som det vil fremgå af det følgende, er der ikke tale om en afstandtagen endsige et opgør med den klassiske socialmedicin, men derimod et forsøg på at vise muligheden af at kunne behandle social ulighed i sundhed på måder, som kan supplere den epidemiologiske forskning. Økonomen og nobelpristageren Amartya Sen peger på nødvendigheden af at inddrage et 1. persons-perspektiv i tillæg til den 3. persons perspektiv som hans egen disciplin, økonomien og epidemiologien, benytter sig af i forståelsen af social ulighed i sundhed (Sen, 2004). Sen nævner Kleinmans forskning som et bidrag til et sådant 1. persons-perspektiv (Kleinman, 2004). 
Bidragene i dette nummer leverer alle materiale til en sådan refleksion. I sit essay om sårbarhed viser Martins artikel "Sårbarhed og sundhed", at sårbarhed må tænkes bredere, end det traditionelt er gjort i sundhedsforskning og sundhedspolitik. Vi har almindeligvis tænkt sårbare grupper som grupper, der på grund af materielle vilkår har øget risiko for sygdom og for tidlig død. Dette er stadig et relevant eller nødvendigt perspektiv, og epidemiologisk forskning har bidraget til at kvalificere denne hypotese videnskabeligt. Men ifølge Martin er sårbarhed et bredere begreb: Et eksistentielt begreb som minder os om, at vi alle er i risiko for alvorlig og livstruende sygdom. Ved at præsentere et helikopterperspektiv på litteraturen inden for det sundhedsfaglige forskningsfelt viser forfatteren de mange forskellige måder, hvorpå sårbarhed i sundhed kan forstås, hvordan dette konstitueres og hvilke implikationer, dette har for de mennesker, der berøres af det. Perspektiver og faktorer, der indvirker på sårbarhed i sundhed, er mange, diverse og påvirker gensidigt hinanden. Martin understreger derfor betydningen af at have øget opmærksomhed på dette i forhold til mere præcist at kunne tale om og udvikle tilbud til grupper, der lider under konsekvenserne af sygdom.

Hvor Martins essay fokuserer på en mere overordnet diskussion af ulighed i sundhed, går resten af artiklerne mere direkte i "kødet" på tematikken gennem konkrete, empiriske beskrivelser og analyser af borgere, der på den ene eller den anden måde oplever konsekvenserne af ulighed i sundhed. Forestillinger om den "rigtige" form for sundhed og livsførelse går igen i flere af artiklerne som et element, der vanskeliggør arbejdet med ulighed i sundhed. Eksempelvis undersøger Braee \& Merrilds artikel "I imagine that they will probably ask about my lifestyle", hvorfor forebyggende helbredsundersøgelser ofte ikke formår at inkludere borgere med lav socioøkonomisk status selvom gruppen er overrepræsenteret i forhold til udfordringer med sygdom og sundhed. Artiklen bygger på en undersøgelse i sociale boligbyggerier og viser, at en central begrundelse for, at borgerne ikke ønsker at deltage i helbredsundersøgelserne, er frygten for at blive mindet om, at de $i k k e$ lever op til dominerende ideer om sund livsførelse. Dette kan virke paradoksalt, idet undersøgelserne netop skal være med til at fremme sundhed for gruppen. Det fremgår desuden, at borgerne faktisk gerne vil leve sundere samt at de både har kendskab til og gør brug af sundhedssystemet. Sidstnævnte afmonterer et af de mest gængse argumenter for, hvorfor det er svært at arbejde med ulighed i sundhed, nemlig at borgerne har manglende viden om sundhedsindsatser. Som alternativ til den herskende praksis for sundhedsforebyggelse på området, foreslår Braee \& Merrild at sådanne initiativer bør tage udgangspunkt i borgernes egne interesser og behov for at forbedre deres sundhed i stedet for en generisk 
forståelse af, hvad den "rigtige", sunde livsførelse er, som tværtimod skaber afstand til borgerne.

Netop udfordringerne ved at præsentere udsatte borgere for en bestemt forståelse af, hvad den "rigtige" løsning på sygdom er, undersøges også i Eilerskovs artikel "Forskønnede billeder i peer-support". Her er fokus på idealet om recovery blandt borgere med psykisk sygdom i en canadisk behandlingsorganisation. I organisationen ønsker man, at brugerne opnår recovery og integration i det omgivende samfund ved at bruge de ansatte, der også lider eller har lidt af psykisk sygdom, som peer-forbilleder. I bestræbelserne på at fremme recovery-processen, skjuler organisationen dog i praksis, at mange ansatte selv oplever udfordringer i forhold til at gennemgå recovery-processen, og der fremsættes herigennem et urealistisk billede af, hvad det vil sige at have opnået recovery. Desuden vægtlægges også det individuelle ansvar i recovery-processen, hvilket betyder, at når det ikke lykkes, så er det alene i den enkelte, at barrieren skal findes. At være udsat med psykisk sygdom er udfordrende i sig selv, og Eilerskov spørger derfor, om det ikke ville være mere givtigt for stedets brugere at inkludere et perspektiv på omverden og de udfordringer, dette inkluderer for psykisk sårbare samt mere åbenhed i forhold til personalets egne udfordringer i den vanskelige recovery-proces.

En overvægt af artiklerne viser, at ulighed i sundhed og udfordringer knyttet hertil bliver mere og mere synlige og omfattende i takt med, at borgerne bliver ældre. Eksempelvis viser Laus artikel "Farmakologik og lægemiddelomsorg" om sårbare ældre, hjemmepleje og medicin, at udbredelsen af medicin i hjemmeplejen har medført en stigende farmakologisk tilgang til arbejdet på bekostning af fokus på sociale effekter af medicinbrug og omsorg for de ældre. Som alternativ til denne tilgang argumenterer Lau for en "lægemiddelomsorgens logik", hvor målet ikke kun er at give og indtage den rigtige medicin korrekt, men også at ældre oplever, at medicinen skaber mening for dem. Problematikker vedrørende 'farmakologiseringen' af hjemmeplejen relaterer sig nok ikke specielt til sårbare og udsatte ældre borgere, men Laus eksempler fra disse borgeres erfaringer understreger de udfordringer, der opstår, når de ældre ikke kan se det meningsfulde i den medicin, de får, og når de derfor i mødet med hjemmeplejen udfordrer den forståelse af compliance og opførsel af patienten, som farmakologiens logik foreskriver.

En anden type problematikker i relation til møder mellem sundhedspersonale og kronisk syge ældre med lav socioøkonomisk status på Lolland beskrives af Jønsson i artiklen "Subjektiv ulighed". Hendes artikel viser, hvordan de ældre gør deres allerbedste for at fremstå som pligtopfyldende, kompetente patienter, og derigennem aktivt søger at afkræfte negative stereotyper, som de oplever knyttes 
sammen med personer med lav socioøkonomisk position. Frygten for at få dårligere behandling grundet deres sociale baggrund leder imidlertid til, at patienterne ikke får spurgt om behandlingsrelaterede ting, de ikke forstår, ikke nævner afvigelser fra den medicinske behandling eller overspiller deres rolle som en "vidende" patient. Jønsson viser, hvordan dette kan resultere i, at vigtig information tabes, behandling bliver mindre optimal eller at borgerne alligevel ender med at blive stigmatiserede som "problempatienter".

Samtidig demonstrerer flere af artiklerne også, at der blandt udsatte ældre borgere eller i deres netværk findes en række ressourcer, som virker fremmende for trivsel og sundhed. I Rytter, Ismail \& Sparres artikel "Alderdom, mad og omsorg" er fokus på plejekrævende minoritetsborgeres familiemedlemmer, der aflønnes kommunalt til at hjælper borgerne med behov for omsorg og pleje i Ishøj og Aarhus. Her er mad og måltider ofte et centralt, konkret stridspunkt mellem de ældre, deres hjælpere og den kommunale visitation. Ifølge artiklen er den kommunale omsorgslogik nøgtern og problemorienteret, hvorfor mad ses som et middel til opnåelse af sundhed, ernæring og velvære samt er en standardiseret ydelse. I modsætning hertil er mad i minoritetsfamilierne ofte et mål i sig selv, og det er motiveret af følelser og helhedsorientering. Artiklen viser, hvordan etniske minoritetsældre ofte udgrænses, fordi de kommunale indsatser tager afsæt i idealtypiske forestillinger om, hvad "dansk ældreliv" indebærer, og fordi de minoritetsetniske familier ofte har nogle ligeledes markante forestillinger om majoritetsdanskernes forhold til mad og måltider. Herigennem betones gensidigt grænsedragningen mellem de ældre minoritetsborgere og det almene velfærdssystem.

En anden borgergruppe, som oplever udgrænsning - og udgrænser sig selv - fra det etablerede velfærds- og sundhedssystem, er de ældre og alderssvækkede alkohol- og stofbrugere, som beskrives i Bach \& Bjerges artikel "Skål i skuret". Grundet bl.a. dårlige erfaringer med systemerne samt manglende vilje til at indordne sig under systemernes rammer, håndteres gruppens stigende sundhedsudfordringer i samværet omkring et drikkeskur på et mindre torv i Aarhus. På den måde fungerer skuret som et slags alternativt hjælpesystem. Dog er samvær og hjælp præget af ambivalens, da "gadens logik" i nogen grad hersker i skuret med potentialer for konflikter, tyveri og usikkerhed i relationernes stabilitet samtidig med, at borgerne bestræber sig på at "opføre sig ordentligt" i forhold til andre brugere af torvet og at drage omsorg for hinanden, når de har brug for hjælp.

Samlet peger artiklerne på faren ved at reducere spørgsmål om ulighed i sundhed til én forklaringsramme f.eks. at udsatte borgere ikke har kendskab til Sundhedsstyrelsens anbefalinger, at de er "ligeglade", og at de ikke selv aktivt søger at 
påvirke deres sundhedstilstand i positiv retning. Tværtimod fristes man til at sige. Det man i første omgang kunne forholde sig mere aktivt til, på et overordnet plan, er, at hvis man reelt vil arbejde med mere lighed i sundhed, så må vi som politikere, forskere, praktikere, pårørende og medborgere i det hele taget udvise mere lydhørhed og respekt i forhold til, at der ikke findes én absolut sandhed om, hvad "sund" og "rigtig" livsførelse er. Ikke dermed sagt at "anything goes", men det er vigtigt at anerkende de små skridt, udsatte borgere selv forsøger at tage f.eks. at skifte fra cigaret til e-cigaret, at forsøge at opføre sig som en "lydig" patient, og at sørge for at de andre i skuret får købt ind. Og herefter reelt stille sig åbne - og måske endda forandringsparate - $\mathrm{i}$ forhold til, hvorfor borgerne ikke altid tager imod de tilbud, de gives for at forbedre deres sundhed i forhold til forebyggelse, hjælp, medicin og pleje etc.

Selvom socialmedicin ikke har så fremtrædende og eksplicit en position i dag som tidligere, så dokumenterer artiklerne et stort behov for, at vi har netop dette perspektiv med, når der arbejdes med at fremme lighed i sundhed. Artiklerne bidrager også med en forståelse af, at lighed i sundhed ikke kun handler om fysisk eller mental sundhed, men også om at være "med" i det samfundsmæssige fællesskab. Det vil sige medborgerskab. Mange af informanterne i artiklerne oplever netop, at de ikke inviteres ind i samfundsfællesskabet - heller ikke, når de har sundhedsmæssige udfordringer.

Vigtigheden af at sammentænke forskellige videnskabelige perspektiver gælder også den anden vej rundt. Det vil sige, at ulighed i sygdom heller ikke alene bør undersøges og forstås ud fra et 1. persons-perspektiv eller rene empiriske antropologiske og sociologiske beskrivelser, men at disse kontinuerligt sættes ind i både en større samfundsmæssig, idehistorisk og biomedicinsk kontekst (hvilket f.eks. ses i den kritiske medicinsk antropologi og den biosociale forskning). Sen (2004) peger således også på nødvendigheden af at sammentænke 1. persons-perspektiver i antropologi og sociologi med epidemiologers, økonomers og filosoffers 3 . personsperspektiver. En sådan tværvidenskabelig forskning er allerede i gang bl.a. i den såkaldte 'social epidemiology', som bl.a. forsøger at forbinde populationers samfundsmæssige erfaringer med epidemiologiske perspektiver (Krieger, 2011).

Da vi sendte callet til dette temanummer ud, havde vi som redaktører håbet på, at forfattere fra flere forskellige discipliner havde meldt sig under fanerne for at engagere sig i en tværfaglig debat om ulighed i sundhed. Hvad tilbageholdenheden fra f.eks. den mediciske verden skyldes, kan vi kun gisne om. Vi håber ikke desto mindre på, at temanummeret alligevel vil blive læst også udover antropologiske og sociologiske kredse, og at det vil bruges som anledning for andre faggrupper 
til at reflektere over og diskutere, hvordan vi som forskere og praktikere aktivt kan forholde sig til og håndtere både forskellighed såvel som ulighed i sundhed i vores daglige virke.

\section{Referencer}

Ackerknecht, E. (1981). Rudolf Virchow. The Development of science. New York: Arno Press, 1981

Anand, S.; Peter, F. \& Sen, A. (2004). Public Heath, Ethics and Equity. Oxford University Press Black, D. \& Morris, J. N. (1980). Inequalities in Health: The Black Repot and the Health Divide. London Penguin.

Bjerge, B. (2009). Mellem vision og praksis: Strukturreformen, rusmiddelbureaukrati og New Public Management. Institute of Sociology, University of Copenhagen. Ph.D.-thesis.

Chadwick, E. (1842). Report on the Sanitary Condition of the Labouring Population of Great Britain: A Supplementary Report on the Results of a Special Inquiry Into the Practice of Interment in Towns.

Christensen, V. (1976). Socialmedicinsk Grundbog. København Munksgaard

Cochrane, A. (1972/2003). Effectiveness and Efficiency: Random Reflections on Health Services. London Royal Society of Medicine Press.

Defactum (2018). Hvordan har du det? Sundhedsprofil og region og kommuner, Bind 1

Diderichsen, F.; Andersen, I. \& Manuel, C. (2011). Ulighed $i$ sundhed - årsager og indsatser. København: Sundhedsstyrelsen.

Foreign Affairs (2016). Inequality. What Causes it. Why it matters, What can be done. New York Council of Foreign Affairs.

Heinild, S. (1968). Hvem er vi. København Rhodos.

Jensen, U. J. (1987 2.udg.). Sygdomsbegreber i Praksis. Munksgaard.

Jensen, U. J. (2004). Evidence, effectiveness and ethics, Cochrane's legacy. In Kristiansen, I.S. \& G. Mooney. Evidence-Based medicine, In its place. London Routledge.

Jensen, U. J. (2010). Patologisering og kampen om sundhedsbegrebet. In Brinkman, S.(ed) Det diagnosticerede liv. Aarhus Klim.

Jensen, U. J. \& Højrup, T. (1993). 'Den suveræne stats krav til borgerne- og borgernes krav til staten'. In Brydensholt, H. Brugeren viser vej. Markedsorientering i den offentlige sektor på godt og ondt. Frederikshavn Dafolo.

Kleinman, A. (2004). 'Ethics and Experience. An Anthropolocial approach to Heatlh Equity' in Anand, S.; Peter, F. \& Sen, A. (eds). Public Heath, Ethics and Equity. Oxford University Press

Krieger, N. (2011). Epidemiology and the people's health. Oxford University Press.

Kymlicka, W. \& Norman, W. (1995). 'Return of the citizen: A survey of recent work on citizenship literature' in Beiner, R. (ed) Theoriizing Citizenship. SUNY Press New York

Marmot, M. et.al. (1991). 'Health Inequalities among British Civil Servants: The Whitehall II, The Lancet, 337 1387-93 Study

Marshall, T. H. (1950/2003). Medborgerskab og social klasse. Hans Reitzel, København

Piketty, T. (2019/2020). Kapital og Ideologi. Informations Forlag København. 
Sodemann, M. (2020). Skal socialt udsatte eller velstillede vælgere forrest i køen til sundhedsvæsenet? Tidsskrift for Dansk Sundhedsvæsen. https:/dssnet.dk/artikler/debat/ morten-sodemann-socialt-udsatte-eller-velstillede-vaelgere/

Sundhedsstyrelsen (2020a). Social ulighed i sundhed og sygdom. Udviklingen i perioden 20102017.

Rosen, G. (1959). 'Hospitals, medical care and social policy in the French revolution'. Bulletin of the History of Medicine, 30, $2,124-149$

Sen, A. (2004). 'Health Achievement and Equity: External and Internal Perspectives'. Anand, S.; Peter, F. \& Sen, A. Public Heath, Ethics and Equity. Oxford University Press Sundhedsstyrelsen (2020b). Indsatser mod ulighed $i$ sundhed.

Vallgardå, S. (2013). Sundhedspolitik. Teorier og analyser. Munksgaard

Vallgardå (2019). Hvordan mindsker vi ulighed $i$ sundhed? Informations forlag

WHO (1986). Sundhed for alle år 2000. København, Dansk Sygeplejeråd

Virchow, R. (1848). Der Armenarzt. Medicinische Reform 18: 125-127.

Virchow, R. (1849) Die Einheitsbestrebungen in der Wissenschaftlischen Medizin. Berlin. 